\title{
The Role of Incentives on the Performance of Health Workers in a Public Sector Organization in Abuja, Nigeria
}

\author{
Nkereuwem, Akpan \\ Post Graduate Student, Faculty of Management Science, \\ Ahmadu Bello University, Zaria, Kaduna State, Nigeria. \\ Email: akpan2k7@yahoo.co.uk
}

(Received: January 10-2021; revised: February 10-2021; published: February 14-2021)

\begin{abstract}
The aim of the research work is to ascertain the role of incentives on the performance of health workers in some selected public sector using Abuja as a case study. Data collection was by the used of selfadministered questionnaires, which were distributed to Doctors and Nurses in some selected public health facilities in Abuja. The statistical Package for Social Sciences (SPSS) software was used for data leaning and analysis. The result obtained from the analysis shows that $64.1 \%$ agreed that incentives brings job satisfaction, 51.4\% agreed that non-monetary incentives promotes organizational performance , $63.3 \%$ agreed that non-monetary incentives promotes good work relationship, 53.7\% agreed that non-monetary incentives reduces stress, $65.3 \%$ agreed that incentives help in the achievement of organizational goal, $58.7 \%$ agreed that incentives serve as a motivation to employees, 57.5\% agreed that incentives help workers to improve skills and qualifications in line with their job and $60.2 \%$ agreed that incentives increase the level of employee's confidence on employer. It was concluded that incentives based on terms and conditions of employment play significant role on the performance of health workers in the public sector, performance based incentives play significant role on the performance of health workers in the public sector, there is significant government attention towards incentives and performance of health care workers in the public sector and non-financial incentives play significant role on the performance of health workers in the public sector.
\end{abstract}

Keywords: Leadership Style; Motivation; Work Discipline.

\section{INTRODUCTION}

Incentives play a major role in employees' productivity. The importance of incentives originates from the need for the employee to be recognized and appreciated for his or her efforts (Agbii et al, 2019). The idea of incentives has resulted in much consideration, especially from the beginning of looking for qualified employees who can efficiently achieve the institution's goals. Appreciating people for their efforts by giving them incentives is a very significant factor in satisfying the internal desires of individuals. The individuals' skills are not enough to let them work with high productivity unless there is an incentive system that encourages their internal motives and then leads very hardworking efforts (Locke \& Braver, 2008).

Palmer (2012) defines incentives as the external temptations and encouraging factors that lead the individual to work harder. They are given due to the individual's excellent performance since he will work harder and produce more effectively when he feels satisfied in the institution. $\mathrm{He}$ also defined incentives as the consideration of the excellent performance, assuming that the salary is enough to make the worker appreciate the value of the job that also satisfies his basic 


\section{Jurnal Ilmiah Ilmu Administrasi Publik: Jurnal Pemikiran dan Penelitian Administrasi Publik}

Volume 11 Number 1, January - Juny 2021. Page 1-14

needs in life (Palmer, 2012). Incentive as a motivational system has historically been used traditionally at a higher level in organizations (Banker et al., 1996; Odey et al., 2019). Although different forms of programmes with the purpose of motivation among regular front line workers have spread, business leaders have embraced different theories of motivation and principalagent relationship realizing that motivation and performance can be created given that proper control tools are used (Merchant \& Van de Steede, 2008).

In Nigeria, especially public organizations, there appears to be a nonchalant attitude of managers towards workers' motivation. The reward system is often not very encouraging (Esu et al., 2009; Irek 2015; Irek 2019). The public sector has limited capability to offer employees certain types of benefits that private companies can offer, such as shareholdings to incentives managers to maximize company performance (Akpan 2021). This also means that politicians and civil servants are less likely to be directly affected by poor performance, compared to managers who may experience financial losses from inefficiencies. The governments often have rigid rules that restrict hiring and firing of civil servants (Aboh 2014; Aboh 2015; Aboh \& Effiong 2019). Civil service systems often use strict formulas that define criteria for hiring, compensation, and promotion compared to the private sector where there is usually more flexibility. These rules have often been designed to prevent politicians from exerting undue influence over civil servants, but they also tend to limit the government's ability to incentivize performance (Dixit, 2002). The fact that public sector organizations serve societal needs may draw different types of individuals into the public sector compared to the private sector, so it can be useful for personnel policies to take this into account (Bessong et al., 2019). In particular, if these individuals are sufficiently motivated to work to the best of their abilities, offering performance pay will increase the government's bill without improving performance.

Public sector organizations often face limited competition in the services provided. Public services like health and education are often heavily subsidized and face limited competition from other providers (Essien 2003; Essien 2005; Fillman 2010; Sudarman \& Laha 2020). This lack of competition may translate into less pressure on employees and a greater need for monitoring as compared to the private sector, where competition helps to incentivize productivity and reduce inefficiency (Rivaton 2018). The general objective of the study is to evaluate the role of incentives on the performance of health workers in the public sector organization in Abuja. The study on the impact of incentives on the performance of health care workers in the public sector will be carried out at the Abuja municipal area council by considering all the existing all functioning public health care facilities in the area council as the study population. Both the management staff and workers at all level will be considered for responses as the impact of incentive affect the entire workforce.

\section{Research Hypothesis}

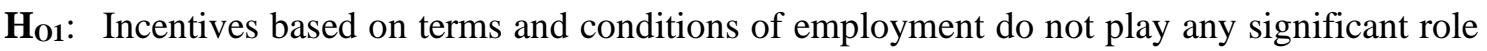
in the performance of health workers in the public sector.

$\mathbf{H}_{\mathbf{1}}$ : Incentives based on terms and conditions of employment play significant role in the performance of health workers in the public sector. 
Ho2: Performance-based incentives do not play any significant role in the performance of health workers in the public sector.

$\mathbf{H}_{2}$ : Performance-based incentives play significant role in the performance of health workers in the public sector.

Ho3: There is no significant government attention towards incentives and performance of health care workers in the public sector.

$\mathbf{H}_{3}$ : There is significant government attention towards incentives and performance of health care workers in the public sector.

$\mathbf{H}_{\mathbf{O} 4}$ : Non-financial incentives do not play any significant role in the performance of health workers in the public sector.

$\mathbf{H}_{4}$ : Non-financial incentives play significant role in the performance of health workers in the public sector.

\section{Operational Definition of Terms}

1. Incentive: Incentive is one which rewards, monetary or non-monetary, are offered to employees and used to stimulate their motivation (Tsai 2018). It is an external persuading factor that encourages the motive which positively directs the individual into working harder, matching the required performance in the institution, as to get the incentive.

2. Motivation: Motivation is a person's degree of willingness toward achieving an individual goal that is consistent with that of the organization and the reasons underlying behavior, which can be either intrinsic or extrinsic (Javid \& Chapa 2014).

\section{METHOD}

According to Dinardo \& Lee (2011), research designs are referred to as the structuring of investigation aimed at identifying variables and their relationships to one another. In this study, a mixed-method approach was employed. This is to ascertain the effect of reward system on employee's performance. Primary and secondary sources were collected through questionnaires and materials. This method was used because it suits the phenomenon under investigation. This agrees with what was stated that the survey only describes a set of data but does not make the judgment.

\section{Population of the study}

The population comprises the totality of units having certain defined characteristics in common (Duncan, 1959). This study was conducted using the staff of public health facilities in Abuja municipal area council. The population of the study covers all the permanent staff Doctors and Nurses of some selected public hospitals. The population of the study comprises of ninety-nine (99) public health facilities in the area of study with an average of three (3) doctors and six (6) nurses in each facility. This total number of doctors and nurses in all the ninety-nine (99) facilities constituted the target population.

\section{Sample Size}



4 Jurnal Ilmiah Ilmu Administrasi Publik: Jurnal Pemikiran dan Penelitian Administrasi Publik
Volume 11 Number 1, January - Juny 2021. Page 1-14

A sample is selected elements (people or objects) chosen for participation in a study. Fowler and Lapp (2019) says a sample only provides an estimate of population characteristic and the accuracy of the estimate will depend on the size of the sample. In general, the larger the sample, the greater the probability that the sample size will be a true representation of the population.

\section{Sample size determination}

The samples size was determined using Yaro-Yamane's statistical formula and it was obtained as follows:

$$
n=\frac{N}{1+N(e)^{2}}
$$

Where $\mathrm{n}$ is sample size; $\mathrm{N}$ is Total population; 1 is a unit known as constant and "e" is the level of significance $(0.05)$ with the above formula. Total population $(N)=99 \times(3+9)=891$ Level of significance $e=0.05$. From the information above:

$$
\begin{aligned}
& n=\frac{891}{1+891(0.05)^{2}} \\
& n=\frac{891}{3.2275}=276
\end{aligned}
$$

Therefore the sample size will be 276

\section{Sampling Technique}

This is the process of examining a representative set of items (people or things) out of the whole population or universe. Systematic sampling technique will be adopted for this study. The population is logically homogenous and after the sample size is decided, the elements of the population will be reached on an interval of one of the available respondents until the required numbers of respondents were obtained.

\section{Research Instrument}

Based on the nature of this work, the researcher employed structured questionnaire and pre-test it for comprehension. The questionnaire will consist of two sections A and B. Items in this section will be designed on 5 points Likert scale with SA for Strongly Agree, A for Agree, $\mathrm{U}$ for undecided, D for Disagree and SD for Strongly Disagree. The formulated questions will be based on the aim of the study; what is the role of incentives on health workers performance in public sector in Abuja municipal area council (AMAC).

\section{Data Collection}

A well-structured questionnaire will be designed and administered to respondents in the selected studylocations.

\section{Data Analysis}

Chi-square statistical tool will be adopted to establish the associationof independent withthe dependent variable. 
$x^{2}=\frac{\left(F_{o}-F_{e}\right)^{2}}{E}$

Where: $X^{2}$ is Chi-square hypothesis distribution; $F_{0}$ is the observed data or frequencies; $F_{e}$ is the expected data or frequencies.

This tool is considered a measure of discrepancies $F_{0}$ and the expected frequencies $F_{e}$. If there is no discrepancy, $X^{2}=0$. As the discrepancy becomes longer, the value of $X^{2}$ is evaluated by the two distributions. The chi-square $X^{2}$ distribution as a statistical tool is also referred toas Goodness of fit.

\section{RESULT AND DISCUSSION}

\section{Results}

\section{Table 1}

\section{Details of questionnaire distributed}

\begin{tabular}{lll}
\hline Age & Frequency & Percentage (\%) \\
\hline Total number of questionnaires administered & 276 & 100 \\
Total number of questionnaires retrieved & 276 & 100 \\
Total number of questionnaires uncollected & 0 & 0 \\
Total number of questionnaires usable & 259 & 93.8 \\
Total number of questionnaires unusable & 17 & 6.2 \\
\hline
\end{tabular}

The Table 1 shows that that total number of questionnaires distributed was 276 . All the questionnaires were retrieved but only 259 representing 93.8 percent are were usable. The unusable 17 questionnaires 6.2 percent was as a result of improper responses and there was no indication of profession on some of the questionnaires. The usable ones are large enough relative to the total administered questionnaires and can be used for the analyses.

Table 2

Gender, age and profession of respondents

\begin{tabular}{llll}
\hline & Category & Number of Respondents & Relative Percentage \\
\hline Gender & Male & 124 & 47.9 \\
& Female & 135 & 52.1 \\
\hline Age & $18-24$ & 65 & 25.1 \\
& $25-32$ & 107 & 41.3 \\
& Above 32 & 87 & 33.6 \\
\hline Profession & Doctor & 41 & 15.8 \\
& Nurse & 218 & 84.2 \\
\hline
\end{tabular}

Two hundred and seventy six (276) copies of questionnaires were given out and 259 were returned valid. Majority of the respondents representing 52.10 percent are female while 47.90 percent of the total respondents are male. The respondents of ages 18-24 ware 65 representing 25.1 percent, the ages of 25-32 years are 107 respondents representing 41.3 percent and ages 

6 Jurnal Ilmiah Ilmu Administrasi Publik: Jurnal Pemikiran dan Penelitian Administrasi Publik Volume 11 Number 1, January - Juny 2021. Page 1-14

above 32 years are 87 respondents representing 33.6 percent. Majority of the respondents $(84.2 \%)$ were nurses and 41 respondents $(15.8 \%)$ are doctors (see Table 2 ).

Table 3

Summary of data collected on responses on the performance of health workers

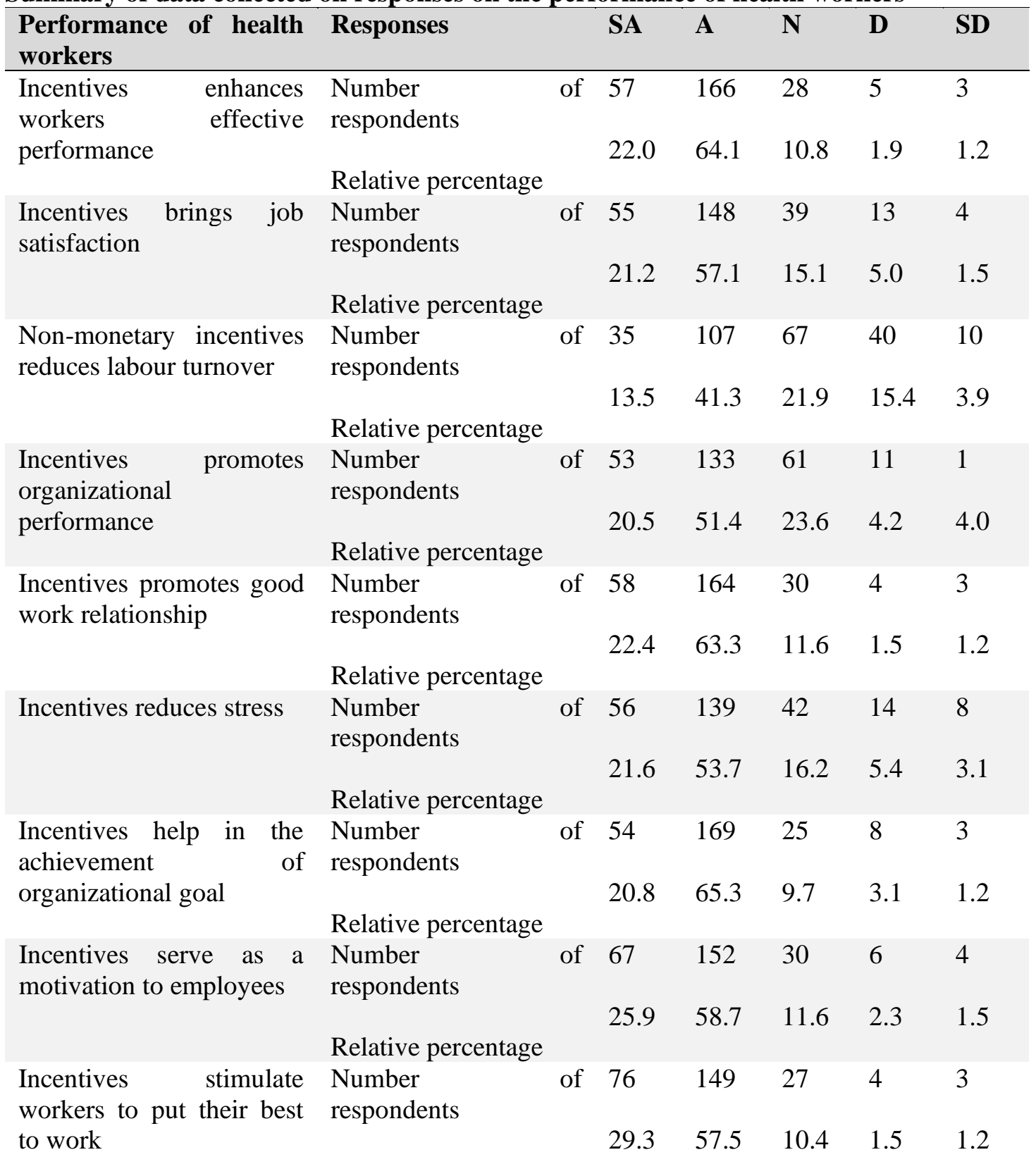




\begin{tabular}{|c|c|c|c|c|c|c|}
\hline $\begin{array}{l}\text { Performance of health } \\
\text { workers }\end{array}$ & Responses & SA & $\mathbf{A}$ & $\mathbf{N}$ & D & SD \\
\hline & Relative percentage & & & & & \\
\hline \multirow{2}{*}{$\begin{array}{l}\text { Incentives help workers to } \\
\text { improve skills and } \\
\text { qualifications in line with } \\
\text { their job. }\end{array}$} & $\begin{array}{l}\text { Number } \\
\text { respondents }\end{array}$ & 44 & 149 & 48 & 12 & 6 \\
\hline & Relative percentage & 17.0 & 57.5 & 18.5 & 4.6 & 2.3 \\
\hline \multirow[t]{2}{*}{$\begin{array}{l}\text { Incentives produces job } \\
\text { security }\end{array}$} & $\begin{array}{l}\text { Number } \\
\text { respondents }\end{array}$ & 43 & 126 & 62 & 19 & 9 \\
\hline & Relative percentage & 16.6 & 48.6 & 23.9 & 7.3 & 3.5 \\
\hline \multirow{2}{*}{$\begin{array}{l}\text { Incentives increase the } \\
\text { level of employees' } \\
\text { confidence on employer. }\end{array}$} & $\begin{array}{l}\text { Number } \\
\text { respondents }\end{array}$ & 54 & 156 & 40 & 5 & 4 \\
\hline & Relative percentage & 20.8 & 60.2 & 15.4 & 1.9 & 1.5 \\
\hline
\end{tabular}

Fifty seven respondents representing $22.0 \%$ Strongly Agree on incentives enhances workers effective performance, 166 respondents representing $64.1 \%$ Agree to incentives enhances workers effective performance, 28 respondents representing $10.8 \%$ were Neutral, 5 respondents representing 1.9\% Disagree on incentives enhances workers effective performance and 3 respondents representing 1.2\% Strongly Disagree on incentives enhances workers effective performance (see Table 3 ).

Fifty five respondents representing 21.2\% Strongly Agree on incentives brings job satisfaction, 148 respondents representing 57.1\% Agree to incentives brings job satisfaction, 39 respondents representing $15.1 \%$ were Neutral, 13 respondents representing 5.0\% Disagree on incentives brings job satisfaction and 4 respondents representing 1.5\% Strongly Disagree on incentives brings job satisfaction (see Table 3 ).

Thirty five respondents representing $13.5 \%$ Strongly Agree on non-monetary incentives reduces labour turnover, 107 respondents representing $41.3 \%$ Agree to non-monetary incentives reduces labour turnover, 67 respondents representing 21.9\% were Neutral, 40 respondents representing $15.4 \%$ Disagree on non-monetary incentives reduces labour turnover and 10 respondents representing 3.9\% Strongly Disagree on non-monetary incentives reduces labour turnover (see Table 3).

Fifty three respondents representing $20.5 \%$ Strongly Agree on incentives promotes organizational performance, 133 respondents representing 51.4\% Agree to incentives promotes organizational performance, 61 respondents representing $23.6 \%$ were Neutral, 11 respondents representing $4.2 \%$ Disagree on incentives promotes organizational performance and 1 respondents representing $0.3 \%$ Strongly Disagree on incentives promotes organizational performance (see Table 3).

Fifty eight respondents representing 22.4\% Strongly Agree on incentives promotes good work relationship, 164 respondents representing $63.3 \%$ Agree to incentives promotes good work relationship, 30 respondents representing $11.6 \%$ were Neutral, 4 respondents representing $1.5 \%$ Disagree on incentives promotes good work relationship and 3 respondents representing $1.2 \%$ Strongly Disagree on incentives promotes good work relationship (see Table 3). 


\section{Jurnal Ilmiah Ilmu Administrasi Publik: Jurnal Pemikiran dan Penelitian Administrasi Publik Volume 11 Number 1, January - Juny 2021. Page 1-14}

Fifty six respondents representing 21.6\% Strongly Agree on incentives reduces stress, 139 respondents representing 53.\% Agree to incentives reduces stress, 42 respondents representing $16.2 \%$ were Neutral, 14 respondents representing $5.4 \%$ Disagree on incentives reduces stress and 8 respondents representing 3.1\% Strongly Disagree on incentives reduces stress (see Table 3).

Fifty four respondents representing 20.8\% Strongly Agree on incentives help in the achievement of organizational goal, 169 respondents representing 65.3\% Agree to incentives help in the achievement of organizational goal, 25 respondents representing $9.7 \%$ were Neutral, 8 respondents representing $3.1 \%$ Disagree on incentives help in the achievement of organizational goal and 3 respondents representing 1.2\% Strongly Disagree on incentives help in the achievement of organizational goal (see Table 3).

Sixty seven respondents representing $25.9 \%$ Strongly Agree on incentives serve as a motivation to employees, 152 respondents representing 58.7\% Agree to incentives serve as a motivation to employees, 30 respondents representing 11.6\% were Neutral, 6 respondents representing 2.3\% Disagree on incentives serve as a motivation to employees and 4 respondents representing $1.5 \%$ Strongly Disagree on incentives serve as a motivation to employees goal (see Table 2).

Seventy six respondents representing 29.3\% Strongly Agree on incentives stimulate workers to put their best to work, 149 respondents representing 57.5\% Agree to incentives stimulate workers to put their best to work, 27 respondents representing 10.4\% were Neutral, 4 respondents representing $1.5 \%$ Disagree on incentives stimulate workers to put their best to work and 3 respondents representing 1.2\% Strongly Disagree on incentives stimulate workers to put their best to work (see Table 3).

Forty four respondents representing $17.0 \%$ Strongly Agree on incentives help workers to improve skills and qualifications in line with their job, 149 respondents representing $57.5 \%$ Agree to incentives help workers to improve skills and qualifications in line with their job, 48 respondents representing $18.5 \%$ were Neutral, 12 respondents representing $4.6 \%$ Disagree on incentives help workers to improve skills and qualifications in line with their job and 6 respondents representing 2.3\% Strongly Disagree on incentives help workers to improve skills and qualifications in line with their job (see Table 3).

Forty three respondents representing 16.6\% Strongly Agree on incentives produces job security, 126 respondents representing 48.6\% Agree to incentives produces job security, 62 respondents representing $23.9 \%$ were Neutral, 19 respondents representing $7.3 \%$ Disagree on incentives produces job security and 9 respondents representing 3.5\% Strongly Disagree on incentives produces job security (see Table 3 ).

Fifty four respondents representing $20.8 \%$ Strongly Agree on incentives increase the level of employees' confidence on employer, 156 respondents representing $60.2 \%$ Agree to incentives increase the level of employees' confidence on employer, 40 respondents representing $15.4 \%$ were Neutral, 5 respondents representing $1.9 \%$ Disagree on incentives increase the level of employees' confidence on employer and 4 respondents representing $1.5 \%$ Strongly Disagree on incentives increase the level of employees' confidence on employer (see Table 3). 


\section{Table 4}

Summary of data collected on responses on themethod of incentives in the public sector

\begin{tabular}{|c|c|c|c|c|c|c|}
\hline $\begin{array}{l}\text { Method of Incentives in } \\
\text { the Public Sector }\end{array}$ & Responses & SA & $\mathbf{A}$ & $\mathbf{N}$ & D & SD \\
\hline Incentives based on terms & Number of respondents & 18 & 141 & 29 & 55 & 16 \\
\hline $\begin{array}{l}\text { and condition of } \\
\text { employment is } \\
\text { implemented in the public } \\
\text { healthcare sector }\end{array}$ & rcentage & 6.9 & 54.4 & 11.2 & 21.2 & 6.2 \\
\hline $\begin{array}{l}\text { Performance is rewarded } \\
\text { in the public healthcare }\end{array}$ & Number of respondents & 29 & 119 & 36 & 57 & 18 \\
\hline sector & Relat & 11.2 & 45.9 & 13.9 & 22.0 & 6.9 \\
\hline $\begin{array}{l}\text { Non- financial incentives } \\
\text { are also given priority in }\end{array}$ & Number of respondents & 26 & 92 & 63 & 67 & 11 \\
\hline $\begin{array}{l}\text { the public healthcare } \\
\text { sector }\end{array}$ & Relative percentage & 10.0 & 35.5 & 24.3 & 25.9 & 4.2 \\
\hline $\begin{array}{l}\text { The government gives } \\
\text { sufficient attention to }\end{array}$ & respondents & 27 & 81 & 63 & 70 & 18 \\
\hline public health care workers & Relative percentage & 10.4 & 31.3 & 24.3 & 27.0 & 6.9 \\
\hline
\end{tabular}

Decision Rule: The $X^{2}$ (chi-square) rules states that where the calculated value is greater, reject the $H_{0}$ where critical greater accept $H_{0}$.

\section{Table 5}

Incentives based on terms and condition of employment is implemented in the public healthcare sector

\begin{tabular}{|c|c|c|c|c|c|}
\hline Items & $\mathbf{O}$ & $\mathbf{E}$ & $F_{O}-F_{E}$ & $\left(F_{0}-F_{e}\right)^{2}$ & $\left(F_{0}-F_{e}\right)^{2} / F_{e}$ \\
\hline Strongly Agree & 18 & 51.8 & -33.8 & 1142.44 & 22.06 \\
\hline Agree & 141 & 51.8 & 89.2 & 7956.64 & 153.60 \\
\hline Neutral & 29 & 51.8 & -22.8 & 519.84 & 10.04 \\
\hline Disagree & 55 & 51.8 & 3.3 & 10.24 & 0.20 \\
\hline Strongly Disagree & 16 & 51.8 & -35.8 & 1281.64 & 24.74 \\
\hline Total & 259 & 259 & 0 & 10910.80 & 210.64 \\
\hline
\end{tabular}

Calculated value: $210.64 ; \quad$ Degree of freedom: 258

Critical value of 0.05 at $258 \mathrm{df}=34.993$ from the $X^{2}$ analysis of the $H_{0}$, the calculated value is 210.64 while critical value is 34.993 (see Table 5). The $H_{1}$ hypothesis is upheld where $H_{0}$ is rejected. It is concluded that incentives based on terms and conditions of employment play significant role on the performance of health workers in the public sector. 
10 Jurnal Ilmiah Ilmu Administrasi Publik: Jurnal Pemikiran dan Penelitian Administrasi Publik Volume 11 Number 1, January - Juny 2021. Page 1-14

Table 6

Performance is rewarded in the public healthcare sector

\begin{tabular}{llllll}
\hline Items & $\mathbf{O}$ & $\mathbf{E}$ & $\mathbf{F}_{\mathbf{0}}-\mathbf{F}_{\mathbf{e}}$ & $\left(\mathbf{F}_{\mathbf{0}}-\mathbf{F}_{\mathbf{e}}\right)^{\mathbf{2}}$ & $\left(\mathbf{F}_{\mathbf{0}}-\mathbf{F}_{\mathbf{e}}\right)^{\mathbf{2}} / \mathbf{F}_{\mathbf{e}}$ \\
\hline Strongly Agree & 29 & 51.8 & -22.8 & 519.84 & 10.04 \\
Agree & 119 & 51.8 & 67.2 & 4515.84 & 87.18 \\
Neutral & 36 & 51.8 & -15.8 & 249.64 & 4.82 \\
Disagree & 57 & 51.8 & 5.2 & 27.04 & 0.52 \\
Strongly Disagree & 18 & 51.8 & -33.8 & 1142.44 & 22.06 \\
Total & 259 & 259 & 0 & 6454.80 & 124.62 \\
\hline
\end{tabular}

Calculated value: $124.62 ; \quad$ Degree of freedom: 258

Critical value of 0.05 at $258 \mathrm{df}=32.741$ from the $X^{2}$ analysis of the $H_{0}$, the calculated value is 124.62 while critical value is 32.741 (see Table 6 ). The $H_{1}$ hypothesis is upheld where $H_{0}$ is rejected. It is concluded that performance based incentives play significant role on the performance of health workers in the public sector.

Table 7

Non-financial incentives are also given priority in the public healthcare sector

\begin{tabular}{llllll}
\hline Items & $\mathbf{O}$ & $\mathbf{E}$ & $\mathbf{F}_{\mathbf{0}}-\mathbf{F}_{\mathbf{e}}$ & $\left(\mathbf{F}_{\mathbf{0}}-\mathbf{F}_{\mathbf{e}}\right)^{\mathbf{2}}$ & $\left(\mathbf{F}_{\mathbf{0}}-\mathbf{F}_{\mathbf{e}}\right)^{\mathbf{2}} / \mathbf{F}_{\mathbf{e}}$ \\
\hline Strongly Agree & 26 & 51.8 & -25.8 & 665.64 & 12.85 \\
Agree & 92 & 51.8 & 40.2 & 1616.04 & 31.20 \\
Neutral & 63 & 51.8 & 11.2 & 125.44 & 2.42 \\
Disagree & 67 & 51.8 & 15.2 & 231.40 & 4.46 \\
Strongly Disagree & 11 & 51.8 & -40.8 & 1664.64 & 32.14 \\
Total & 259 & 259 & 0 & 4303.16 & 83.07 \\
\hline
\end{tabular}

Calculated value: 83.07; Degree of freedom: 258

Critical value of 0.05 at $258 \mathrm{df}=33.279$ from the $X^{2}$ analysis of the $H_{0}$, the calculated value is 83.07 while critical value is 33.297 (see Table 7). The $H_{1}$ hypothesis is upheld where $H_{0}$ is rejected. It is concluded that there is significant government attention towards incentives and performance of health care workers in the public sector.

\section{Table 8}

The government gives sufficient attention to public health care workers

\begin{tabular}{llllll}
\hline Items & $\mathbf{O}$ & $\mathbf{E}$ & $\mathbf{F}_{\mathbf{0}}-\mathbf{F}_{\mathbf{e}}$ & $\left(\mathbf{F}_{\mathbf{0}}-\mathbf{F}_{\mathbf{e}}\right)^{\mathbf{2}}$ & $\left(\mathbf{F}_{\mathbf{0}}-\mathbf{F}_{\mathbf{e}}\right)^{\mathbf{2}} / \mathbf{F}_{\mathbf{e}}$ \\
\hline Strongly Agree & 27 & 51.8 & -24.8 & 615.04 & 11.87 \\
Agree & 81 & 51.8 & 29.2 & 852.64 & 16.46 \\
Neutral & 63 & 51.8 & 11.2 & 125.44 & 2.42 \\
Disagree & 70 & 51.8 & 18.2 & 331.24 & 6.40 \\
Strongly Disagree & 18 & 51.8 & -33.8 & 1142.44 & 22.06 \\
Total & 259 & 259 & 0 & 3066.80 & 59.21 \\
\hline
\end{tabular}

Calculated value: 59.21;Degree of freedom: 258 
Critical value of 0.05 at $258 \mathrm{df}=30.156$ from the $X^{2}$ analysis of the $H_{0}$, the calculated value is 59.21 while critical value is 30.156 (see Table 8 ). The $H_{1}$ hypothesis is upheld where $H_{0}$ is rejected. It is concluded that non-financial incentives play significant role on the performance of health workers in the public sector.

\section{Discussion}

The number of male respondent is 124 representing $47.9 \%$, female respondent is 135 representing $52.1 \%$. This shows that the number of male and female health workers is almost the same. Therefore the report is not affected by gender differences as may be classified by some of the incentives that may be gender sensitive. Respondents within the age group of $25-$ 32 are 107 representing $41.3 \%$ is the highest followed by age above 32 representing $33.6 \%$. Respondent of age $18-24$ are the least with 65 representing $25.1 \%$. This shows that the health workers with long period of service are more. From the statistical analysis, the numbers of respondents that are Doctors are 41 representing $15.8 \%$ while respondents that are nurses are 218 representing $84.2 \%$. This clearly shows that $100 \%$ of the respondents are medical personnel and were fit to respond to the questionnaire.

The study empirically examined the role of incentives on the performance of health workers in the public sector. According to this study, the role of incentive system in the public health sector include enhancement of workers effective performance, job satisfaction, reduction of labour turnover, promotion of organizational performance, promotion of good work relationship, reduction of stress, achievement of organizational goal, motivation to employees and stimulation of workers to put their best to work. From the analysis, 166 respondents representing the highest percentage $(64.1 \%)$ agreed that incentives enhances workers effective performance. 148 respondents representing the highest percentage $(57.1 \%)$ agreed that incentives brings job satisfaction. 107 respondents representing the highest percentage $(41.3 \%)$ agreed that non-monetary incentives reduces labour turnover. 133 respondents representing the highest percentage $(51.4 \%)$ agreed that non-monetary incentives promotes organizational performance. 164 respondents representing the highest percentage $(63.3 \%)$ agreed that nonmonetary incentives promotes good work relationship. 139 respondents representing the highest percentage (53.7\%) agreed that non-monetary incentives reduces stress. 169 respondents representing the highest percentage $(65.3 \%)$ agreed that incentives help in the achievement of organizational goal. 152 respondents representing the highest percentage $(58.7 \%)$ agreed that incentives serve as a motivation to employees. 149 respondents representing the highest percentage $(57.5 \%)$ agreed that incentives help workers to improve skills and qualifications in line with their job. 126 respondents representing the highest percentage $(48.6 \%)$ agreed that incentives produces job security. 156 respondents representing the highest percentage $(60.2 \%)$ agreed that incentives increase the level of employees' confidence on employer.

Considering the hypothetical analysis, the following can be inferred for the null hypotheses:

$\mathbf{H}_{01}$ : In this hypothesis, it is revealed thatincentives based on terms and conditions of employment play significant role on the performance of health workers in the public sector. 
12 Jurnal Ilmiah Ilmu Administrasi Publik: Jurnal Pemikiran dan Penelitian Administrasi Publik

Volume 11 Number 1, January - Juny 2021. Page 1-14

$\mathbf{H}_{\mathbf{0 2}}$ : In this hypothesis, it is revealed thatincentives play significant role on the performance of health workers in the public sector.

. $\mathbf{H}_{03}$ : In this hypothesis, it is revealed thatthere is significant government attention towards incentives and performance of health care workers in the public sector.

H04: In this hypothesis, it is revealed thatnon-financial incentives play significant role on the performance of health workers in the public sector.

The results are in conformity with the works of Sittenthaler and Mohnen (2020) who postulated that non- monetary incentives are focused on recognition, opportunity and career advancement. Also, Dr. Nelson postulated that monetary incentives are tangible returns which include bonus, increment, benefits and allowance that contributed to the positive impact of employee's performance (Read, 2005). The study is also in conformity with the works of Feyisetan and Simperl (2019) who opined that monetary incentives are profit sharing, job evaluation and merit rating that are given to all employees in that organization and is distributed based on their performance.

\section{CONCLUSION}

The study empirically examined on the role of incentives on the performance of health workers in the public sector in Abuja, Nigeria. While research into incentives relating to performance of health workers is not a new phenomenon in the academic literature, this study streamlined its work and explored further into the role incentives play in public health sector in Abuja. Following analysis from the data gathered, it was inferred that are very key to the performance of employees in the public sector as enhances workers effective performance, brings job satisfaction, reduces labour turnover, promotes organizational performance, promotes good work relationship, reduces stress, help in the achievement of organizational goal, serve as a motivation to employees, stimulate workers to put their best to work, help workers to improve skills and qualifications in line with their job, produces job security and increase the level of employees' confidence on employer. These inferred outcomes are roles played by incentives in organizations (including the public health sector). Incentives are planned activities that organizations implement towards its employees to achieving the set goals of the organization.

From the result obtained, the Federal Government must commit to pay attention to incentive systems application and put it into force for better performance of public sector workers in general. The health public sector's success relies, in the first place, upon working individuals' performance. In this sight, the government should take care of workers and work on having them motivated in order for their abilities and skills to be elevated because achieving high level of quality depends upon those workers' behavior toward beneficiaries of public health services. Thus, incentives perform a huge role in any organization failure or success in service delivery. 


\section{REFERENCES}

Aboh, J. A. (2014). Conflict management: A panacea to development. Sophia: An African Journal of Philosophy, 14(2), 64-67.

Aboh, J. A. (2015). Assassinating political opposition: An" Albatross" and aberration-the Cross River example. Sophia: An African Journal of Philosophy, 16(1), 211-215.

Aboh, J. A. (2015). Child labour and forced marriage: Modern slavery in Nigeria. Sophia: An African Journal of Philosophy, 15(2), 15-19.

Aboh, J. A., \& Effiong, E. N. (2019). A Historical Periscope of Self Inflicted Socio-Political Predicaments of Nigerians.

Agbii, S. U., Chukwu, C. E., \& Iwundu, N. (2019). Enhancing Human Capital Development through Higher Education. GNOSI: An Interdisciplinary Journal of Human Theory and Praxis, 2(1), 48-55.

Akpan, N. (2021). The Factors Militating Against the Globalization of Technology Market in Nigeria: Case Study of Abuja. GNOSI: An Interdisciplinary Journal of Human Theory and Praxis, 4(2), 18-30.

Banker, R. D., Lee, S. Y. \& Potter, G. (1996). A field study of the impact of a performancebased incentive plan. The journal of accounting and economics, vol. 21, no. 2, pp. 195226.

Bessong, P. K., Bassey, B. E., \& Nwafor, B. C. (2019). Impact of Social Cost Accounting on Corporate Performance of Petroleum Marketing Firms in Nigeria. GNOSI: An Interdisciplinary Journal of Human Theory and Praxis, 2(1), 1-9.

Dinardo, J., \& Lee, D. S. (2011). Program Evaluation and Research Designs. In Handbook of Labor Economics (Vol. 4, Issue PART A). https://doi.org/10.1016/S01697218(11)00411-4

Dixit, A. (2002). 'Incentives and Organisations in the Public Sector'.Journal of Human Resources XXXVII.

Duncan, O. D. (1959). Human Ecology and Population Studies. In The Study of Population (pp. 678-716).

Essien, E. (2003). The Performing Artist and Marketing Problems in Nigeria. Theatre Studies Review, 3(1), 44-55.

Essien, E. (2005). The Theatre Administrator and Conflict Resolution in the Theatre. Nduñode, $6(2), 21-28$

Esu, B., \& J. Inyang, B. (2009). A Case for Performance Management in the Public Sector in Nigeria. International Journal of Business and Management, 4(4). https://doi.org/10.5539/ijbm.v4n4p98

Feyisetan, O., \& Simperl, E. (2019). Beyond Monetary Incentives. ACM Transactions on Social Computing, 2(2), 1-31. https://doi.org/10.1145/3321700

Fillman, D. S. (2010). Diabetes education and public health services. In The Diabetes educator (Vol. 36, Issue 3, pp. 363-364). https://doi.org/10.1177/0145721710370947

Fowler, S. B., \& Lapp, V. (2019). Sample size in quantitative research. American Nurse Today Research, 14(5), 61-61. 
14 Jurnal Ilmiah Ilmu Administrasi Publik: Jurnal Pemikiran dan Penelitian Administrasi Publik Volume 11 Number 1, January - Juny 2021. Page 1-14

Irek, N. E. (2018). Prophetic Reflection on Good Governance in Nigeria: Discourse on Chinua Achebe's The Trouble with Nigeria Chinua Achebe and the Convolution of Immortality.

Irek, N. E., \& Charles, E. (2015). Theatre Practice in Nigeria: Surveying the Past and Present. Ifok Journal of Interdisciplinary Studies, 2(1).

Javid, B. S., \& Chapa, A. (2014). When Money is not a Motivating Force in the Work Place. Global Journal of Human-Social Science: A Arts \& Humanities - Psychology, 14(3), 0-6.

Locke, H. S. \& Braver, T. S. (2008). "Motivational Influences on Cognitive Control: Behavior, Brain Activation, and Individual Differences. Cogn. Affect. Behav.Neurosci." 8(99), 2008.

Merchant, K. A. \& Van de Steede, W. A. (2008).Management Control Systems. Essex, UK: Pearson Education Limited.

Odey, J. S., Ajor, J. O., \& Aboh, J. O. (2019). The Place of History in Mitigating National Challenges: The Case of Nigeria. International Journal of Recent Innovations in Academic Research, 3(3), 23-31.

Palmer, W. (2012). "Incentive and Disincentive: Will They Affect Performance.",

Read, D. (2005). Monetary incentives, what are they good for? Journal of Economic Methodology, 12(2), 265-276. https://doi.org/10.1080/13501780500086180

Rivaton, R. (2018). “The era of weak competition.” In Concurrences (Vol. 2018, Issue 2, pp. 4 9).

Sittenthaler, H. M., \& Mohnen, A. (2020). Cash, non-cash, or mix? Gender matters! The impact of monetary, non-monetary, and mixed incentives on performance. Journal of Business Economics, 90(8), 1253-1284. https://doi.org/10.1007/s11573-020-00992-0

Sudarman, F., \& Laha, M. S. (2020). The Public's Perception of the Government Employees' Services at Fandoi District, Biak Numfor Regency, Papua Province. GNOSI: An Interdisciplinary Journal of Human Theory and Praxis, 3(3), 97-111.

Tsai, S. N. (2018). Innovative behaviour of knowledge workers and social exchange attributes of financial incentive: implications for knowledge management. Journal of Knowledge Management, 22(8), 1712-1735. https://doi.org/10.1108/JKM-07-2017-0293 